\title{
ARTERIAL VASCULARIZATION OF THE CLOACAL BURSA OF GREATER RHEA, Rhea americana americana LINNAEUS, 1758
}

\author{
VASCULARIZAÇÃO ARTERIAL DA BOLSA CLOACAL DE EMA, Rhea \\ americana americana Linnaeus, 1758
}

\author{
Radan Elvis Matias de OLIVEIRA ${ }^{1}$; Gleidson Benevides de OLIVEIRA $^{2}$; \\ Ferdinando Vinicius Fernandes BEZERRA ${ }^{2}$; Felipe Venceslau CÂMARA ${ }^{2}$; \\ Herson da Silva COSTA ${ }^{3}$; André Vinícius Nunes SILVA ${ }^{3}$; \\ Hélio Noberto de ARAÚJO JÚNIOR ${ }^{3}$; Moacir Franco de OLIVEIRA ${ }^{4}$ \\ 1. Mestrando em Ciência Animal, Departamento de Ciências Animais, Universidade Federal Rural do Semi-Árido - UFERSA, \\ Mossoró, RN, Brasil. radan_elvis@ @otmail.com; 2. Doutorando em Ciência Animal, Departamento de Ciências Animais - \\ UFERSA, Mossoró, RN, Brasil; 3. Graduando em Medicina Veterinária, Departamento de Ciências Animais - UFERSA, \\ Mossoró, RN, Brasil; 4. Professor, Doutor, Departamento de Ciências Animais - UFERSA, Mossoró, RN, Brasil.
}

\begin{abstract}
The cloacal bursa is an organ in fowls, which triggers lymphocyte maturation and transference to other tissues. Since there is scanty information on its morphology in wild species in spite of its importance in the fowls' immunological system, current analysis describes the arterial vascularization of the cloacal bursa in the greater rhea. Twenty juvenile rheas (male and female), which died of natural causes, were obtained from the Center for the Multiplication of Wild Animals (CEMAS/UFERSA). The animals were dissected and their thoracic aorta cannulated and red-stained Latex Neoprene 650 was introduced. The cloacal bursa was irrigated from the terminal branches of the abdominal aorta similar to the caudal mesenteric artery and to the right and left internal iliac arteries. The right and left internal pudenda arteries originated from the right and left internal iliac arteries which, in their turn, gave rise to cloacalbursa arteries and to the right and left cloacal arteries in all studied animals. The caudal mesenteric artery contributed to the arterial blood of the cloacal bursa in almost all studied animals through the anastomosis of right or left internal pudenda artery, with direct branches to the cloacal bursa. The cloacal bursa of the greater rhea is irrigated by cloacal-bursa arteries and cloacal right and left and also by the mesenteric caudal artery, with small variations with regard to the number and layout of the anastomoses and branches from the arteries. The latter are specific characteristics and differentiate them from standards perceived in other fowls.
\end{abstract} Ratites.

KEYWORDS: Cloacal-bursa artery. Cloacal artery. Fowls. Immunological system. Mesenteric caudal artery.

\section{INTRODUCTION}

The greater rhea is the biggest native fowl in South America and, together with the ostrich, emu, cassowary and kiwi, belong to the Ratite group. The fowl belongs to the Struthionoform order and the family Rheidae, characterized by their reproductive adaptability and the byproducts such as meat, hide, feathers and fat (ALMEIDA, 2003).

The meat of rhea is source of animal protein appreciated for its low lipid rates (1.59\%) and low collagen contents providing softness to meat. In fact, it is a healthy product for human consumption (PEREIRA et al., 2006). Its breeding is highly appropriate within a sustainable production system. Studies on the biology and morphology of the species are required so that animal-improvement characteristics of the species could be better exploited in Brazil.

Morphological knowledge is highly important for health, feed and reproduction management in captivity and to provide basic data for clinical and surgical procedures. The literature provides few morphological studies with females (PARIZZI et al., 2007), cloaca of the males (SANTOS et al., 2011), digestory apparatus (RODRIGUES et al., 2012a; RODRIGUES et al., $2012 \mathrm{~b}$ ) and morphology of the blood cells (FORTES et al., 2009) in the rhea. There is no information on the morphology and vascularization of the cloacal bursa of the rhea.

Arterial vascularization is responsible for transportation of blood rich in oxygen, which is essential for maintenance of biological organs. The arterial vascularization of the cloacal bursa is essential for the development of the fowls' immunological function. Pioneer work by Ackermann (1962) and Frazier (1974), who described the vascular patterns in fowls, should be underscored, coupled to analyses by Pintea et al. (1967) and Zamojska (1975), who detailed the irrigation of the cloacal bursa in the genus Gallus. Further, other studies have been developed in domestic fowls such as pigeons (BAUMEL, 1988; 
ABBATE et al., 2007), ducks (SCALA et al., 1989), guinea fowls (ONYEANUSI et al., 1993) and ostriches (HONORATO et al., 2009).

Since the arterial vascularization of the cloacal bursa is very important for the development of fowls' immunological function, this study was undertaken to describe the arterial vascularization of the cloacal bursa by identifying the origin, number and the distribution of arteries that contribute directly or indirectly towards the organ's blood supply. Information on the species's biology and comparative anatomy is thus provided.

\section{MATERIAL AND METHODS}

Twenty young male and female rheas (15 females and 5 males, aged between 4 and 8 weeks old) were used in the assay. They had died of naturally causes and were kept frozen at the Center for the Multiplication of Wild Animals (CEMAS) at the Universidade Federal Rural do Semi-Árido (UFERSA). The scientific breeding center is registered at IBAMA (Register n. 1478912) and the collection of the animals was authorized by (SISBIO) under protocol 47371-1 and by the Committee for Ethics in the Use of Animals (CEUA/UFERSA), under Register 23091.004968/2015-23.

The animals were thawed and an incision was made on the ventral region of the abdomen to expose the thoracic aorta which was cannulated in a caudal direction. The vascular system was washed in a saline solution $0.9 \%$ and latex Neopreme 650 (Du Pont do Brasil S.A.), stained with a specific red hue (Globo S.A. Tintas e Pigmentos), was introduced. After injection of the latex, the animals were fixed in water solution of formaldehyde $10 \%$ and after 72 hours dissections and analyses of the structures were performed. Sketches for each vascular arrangement were drawn and the most representative examples were photographed by digital camera Sony DSC-W570 16.1 MP.

The study was based on the nomenclature used by the Handbook of Avian Anatomy: Nomina Anatomica Avium (BAUMEL et al., 1993) to name the identified structures. Results were compared to the literature on domestic and wild fowls. Results were given in descriptive anatomy and assessed by simples percentage calculations.

\section{RESULTS}

The cloacal bursa is a hollow, rounded and pale-colored or slightly beige-colored organ, with highly internal sticky mucus. It lies dorsally about the cloaca with which it communicates through an orifice. The arterial irrigation of the organ originated from terminal branches of the abdominal aorta, such as the right and left internal iliac arteries and the caudal mesenteric artery (Figure 1A). The right and left internal iliac arteries gave rise to the right and left pudendal internal arteries which, in their turn, provided the cloacal-bursa arteries and the right (Figure 1E) and left (Figure 1F) cloacal arteries in all studied animals (Figure 2).

\section{Cloacal-bursa arteries}

The left and right cloacal-bursa arteries derived respectively from the left and right internal pudenda arteries and directly contributed to the arterial blood provision of the cloacal bursa artery in all studied animals. The right cloacal-bursa artery in the right antimere varied in number, with a single right cloacal-bursa artery (65\%), and two $(30 \%)$ or three $(5 \%)$ arteries originating from the internal right pudendal artery. Similarly, one (75\%), two $(20 \%)$ or three $(5 \%)$ cloacal-bursa left arteries, derived from a common origin, have been reported on the left antimere.

Three distinct directions of the arterial pathways have been registered. In the first case, a cloacal-bursa artery in the two antimeres branches, dorsally and laterally positioned to the dorsal and caudal region of the cloacal bursa in all the specimens (Figures $1 \mathrm{E}$ and $1 \mathrm{~F}$ ) were found. In the second case, the right cloacal-bursa artery covered the cranial-dorsal surface of the cloacal bursa in five specimens $(25 \%)$ at the right antimere (Figure 1E) and in three (15\%) at the left antimere (Figure 1F). In the third case, it passed the cranial-ventral region of the cloacal bursa at the right antimere in three specimens (15\%) and at the left antimere in two specimens (10\%) (Figure 1F).

Variations were reported between two and nine branches emitted by the right cloacal-bursa arteries, with two branches in four specimens (20\%), three branches in two specimens (10\%), four branches in five specimens (25\%), five branches in four specimens (20\%), six branches in two specimens (10\%), seven branches in two specimens $(10 \%)$ and nine branches in one specimen $(5 \%)$. The left cloacal-bursa arteries emitted between one and seven branches towards the left antimere, or rather, one branch in one specimen (5\%), two branches in four specimens $(20 \%)$, three branches in two specimens (10\%), four branches in seven specimens $(35 \%)$, five branches in two specimens (10\%), six in two specimens $(10 \%)$ and seven branches in two specimens (10\%) (Table 1). 


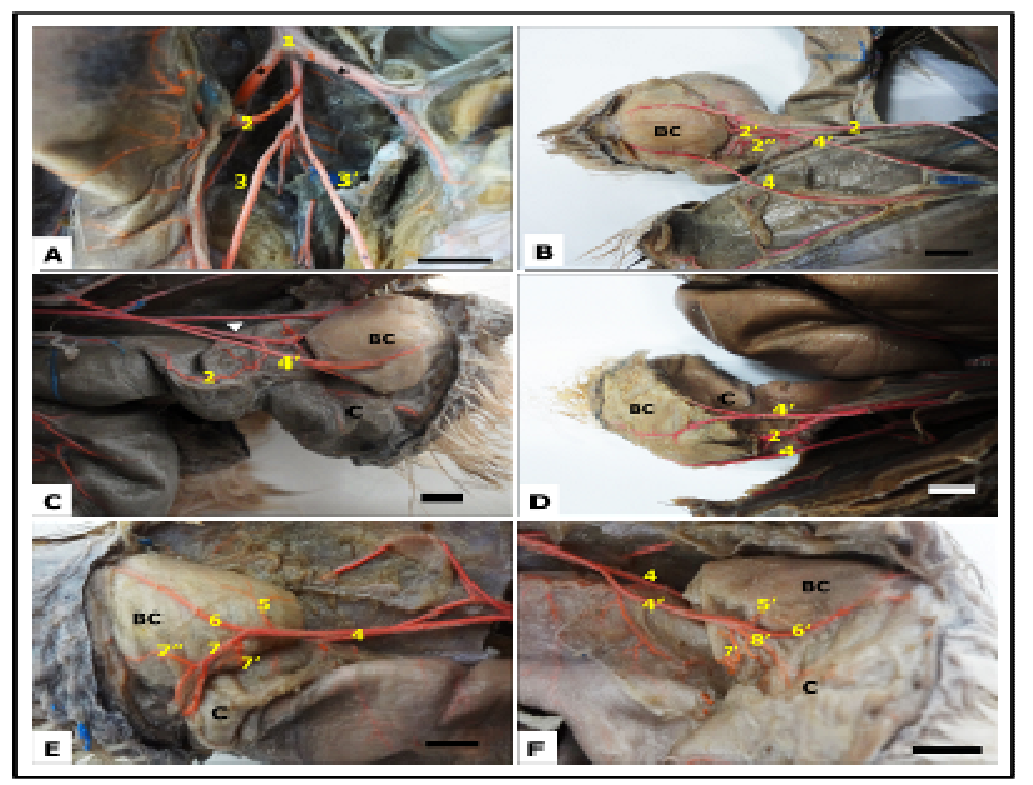

Figure 1. Arterial vascularization of the cloacal bursa of the Rhea. 1A: note, from the ventral side, the terminal branches of the abdominal aorta (1), sciatic arteries (*), caudal mesenteric artery (2) and right internal iliac artery (3) and left internal iliac artery (3'). 2B: Note, from the dorsal side of the cloacal bursa, $(\mathrm{CB})$, the caudal mesenteric artery (2) with emission of rays (2' and 2"), and right (4) and left (4') internal pudenda arteries. 1C: note, from the left lateral side, the cloacal bursa (CB) placed dorsally to the cloaca (C), anastomosis of the caudal mesenteric artery (2) with a branch of the right internal pudenda artery (arrow head), and also the left internal pudenda artery (4'). 1D: note from the left lateral view, the caudal mesenteric artery anastomosed into the left internal pudenda artery (4') and the right internal pudenda artery (4). 1E, note from the right lateral view, the right internal pudenda artery (4) giving rise to the right cranial-dorsal cloacal bursa arteries (5), right dorsal-lateral cloacal bursa artery (6), right cloacal artery (7), the later emitting two branches (7' and 7') towards the cloacal bursa (CB). 1F: note, from the left lateral view, the left internal pudenda artery (4'), emitting the left cranial-dorsal cloacal bursa artery (5'), left dorsal-lateral cloacal bursa artery (6'), left cranial-ventral cloacal bursa artery ( $\left.7^{\prime}\right)$, left cloacal artery $\left(8^{\prime}\right)$, and the right internal pudenda artery (4). Bar: $1 \mathrm{~cm}$.

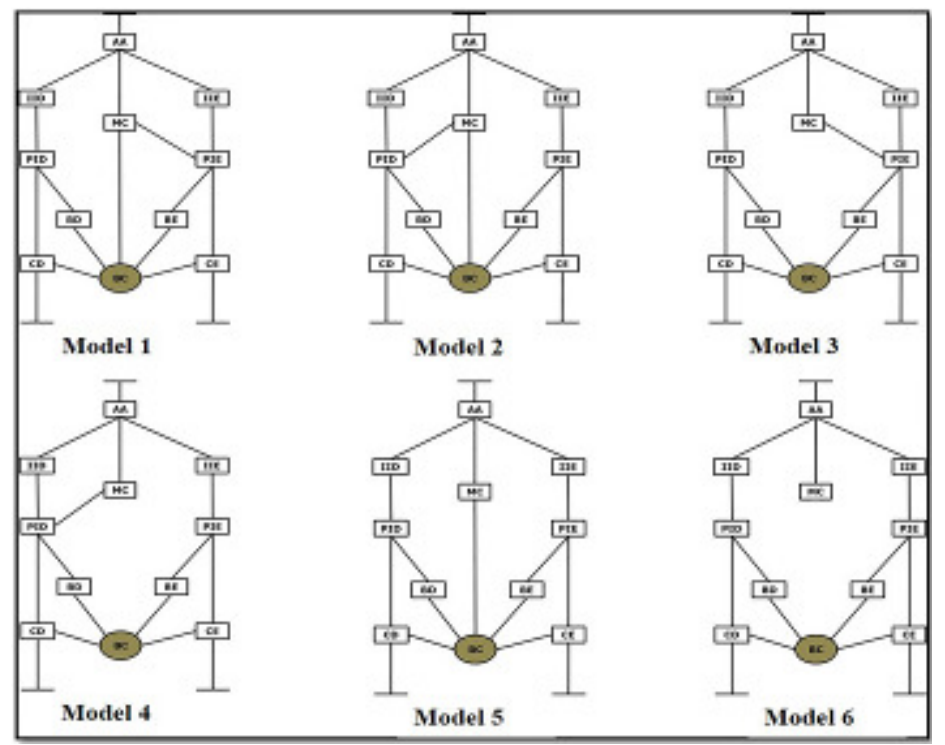

Figure 2. Vascularization models of the cloacal bursa identified in the rhea from the caudal mesenteric artery. Abdominal aorta artery (AA), right internal iliac artery (IID), left internal iliac artery (IIE), right internal pudenda artery (PID), left internal pudenda artery (PIE), right cloacal bursa artery (BD), left cloacal bursa artery $(\mathrm{BE})$, right cloacal artery $(\mathrm{CD})$, left cloacal artery $(\mathrm{CE})$ and caudal mesenteric artery (MC). 
Table 1. Absolute (N) and relative (\%) frequency of branches emitted by the cloacal-bursa and cloacal arteries from the right and left antimeres to supply the rheas' cloacal bursa.

\begin{tabular}{|c|c|c|c|c|c|c|c|c|}
\hline \multirow{3}{*}{ Branches } & \multicolumn{4}{|c|}{ Cloacal-bursa artery } & \multicolumn{4}{|c|}{ Cloacal artery } \\
\hline & \multicolumn{2}{|c|}{ D } & \multicolumn{2}{|c|}{$\mathbf{E}$} & \multicolumn{2}{|c|}{ D } & \multicolumn{2}{|c|}{$\mathbf{E}$} \\
\hline & $\mathbf{N}$ & $\%$ & $\mathbf{N}$ & $\%$ & $\mathbf{N}$ & $\%$ & $\mathbf{N}$ & $\%$ \\
\hline 1 & - & - & 1 & 5 & 7 & 41.18 & 4 & 21.05 \\
\hline 2 & 4 & 20 & 4 & 20 & 5 & 29.41 & 9 & 47.38 \\
\hline 3 & 2 & 10 & 2 & 10 & 3 & 17.65 & 4 & 21.05 \\
\hline 4 & 5 & 25 & 7 & 35 & 2 & 11.76 & 1 & 5.26 \\
\hline 5 & 4 & 20 & 2 & 10 & - & - & 1 & 5.26 \\
\hline 6 & 2 & 10 & 2 & 10 & - & - & - & - \\
\hline 7 & 2 & 10 & 2 & 10 & - & - & - & - \\
\hline 8 & - & - & - & - & - & - & - & - \\
\hline 9 & 1 & 5 & - & - & - & - & - & - \\
\hline Total & 20 & 100 & 20 & 100 & 17 & 100 & 19 & 100 \\
\hline
\end{tabular}

\section{Cloacal arteries}

The right and left cloacal arteries originated from the right and left internal pudenda arteries respectively, and they branched to the ventral-lateral region of the cloacal bursa throughout their pathway towards the cloaca (Figures 1E and 1F). Further, the right cloacal artery supplied blood to the organ in the seventeen specimens studied (85\%), whereas the left one did so in nineteen specimens (95\%). It should be underscored that in animals with no participation of the right cloacal artery in the irrigation of the cloacal bursa, the organ was replaced by two right cloacal-bursa arteries, compensating the lack of the right cloacal artery.

The right cloacal artery, throughout the pathway towards the cloaca, gave rise to one branch in seven specimens $(41.18 \%)$, two in five specimens $(29.41 \%)$, three in three specimens $(17.65 \%)$ or four branches in two specimens $(11.76 \%)$, whereas the left cloacal artery gave rise to one branch in four specimens $(21.05 \%)$, two in nine specimens $(47.38 \%)$, three in four specimens $(21.05 \%)$, four in one specimen $(5.26 \%)$ and five in one specimen $(5.26 \%)$ (Table 1).

\section{Caudal mesenteric artery}

The caudal mesenteric artery contributed directly or indirectly towards the arterial blood supply of the cloacal bursa in seventeen specimens studied (85\%). It contributed directly when it provided small branches to the cloacal bursa when anastomosed or not with the right and left internal pudenda arteries and indirectly when anastomosed with the right and left internal pudenda arteries.

The caudal mesenteric artery anastomosed with the right internal pudenda artery in seven specimens (35\%) (Figure 1C and Figure 2) and with the left internal pudenda artery in eight specimens (40\%) (Figure 1D and Figure 2). When associated with the right internal pudenda artery, the caudal mesenteric artery branched towards the cloacal bursa in three specimens (15\%) and two in one specimen (5\%); when associated to the left internal pudenda artery, it branched in one specimen (5\%) and in two branches in two specimens (10\%). On the other hand, the caudal mesenteric artery also gave rise to direct branches towards the cloacal bursa in two specimens (10\%), with one branch $(5 \%)$ or three branches $(5 \%)$ (Figure 1B and Figure 2).

\section{DISCUSSION}

The cloacal bursa of the rhea is a distinct structure from the cloaca, with specific irrigation, as reported in ducks (SCALA et al. 1989), hens (SANTANA et al., 1999), pigeons (ABBATE et al., 2007) and ostriches (HONORATO et al., 2009).

The irrigation of the cloacal bursa in the rhea occurs from the terminal vessels of the abdomen aorta, especially from the branches of the right and left internal iliac arteries. These arteries gave rise to the right and left internal pudenda arteries from which originated the cloacal-bursa arteries and the right and left cloacal arteries in all studied animals, or rather, vessels which irrigate the cloacal bursa. Present results corroborate with the studies on the Gallus gallus domesticus, strains Peterson (SANTANA et al., 1999), NPK (SILVA et al., 2001), Label Rouge (SILVA et al., 2003), Lhoman White LSL (LIMA et al., 2008) and Master Gris Cou Plumé (ROSA et al., 2014).

Besides the internal iliac arteries, the caudal mesenteric artery, originating from the abdomen artery, also irrigated the cloacal bursa of the rhea, similar to reports on the different strains of Gallus gallus domesticus (SANTANA et al., 1999; 
SANTANA et al., 2000; SANTANA et al., 2003) and the ostrich (HONORATO et al., 2009).

Scala et al. (1989) and Silva et al. (1997) respectively studied the vascularization of the cloacal bursa in ducks and Ross hens and reported the right and left internal pudenda arteries which irrigated the cloacal bursa and give rise to branches that discharged on the parenchyma of the cloacal bursa. On the other hand, Santana et al. (1999), Silva et al. (2001), Silva et al. (2003) and Rosa et al. (2014) studied different strains of hens, respectively Peterson, NPK, Label Rouge and Master Gris Cou Plumé, and described that, besides the right and left internal pudenda arteries, the cloacal-bursa arteries and right and left cloacal arteries also irrigated the cloacal bursa, as reported by the Nomina Anatomica Aviaria (BAUMEL et al., 1993), with a similar standard as registered in rheas.

The right internal pudenda artery in the rhea irrigated the cloacal bursa in all the specimens and emitted one to three right cloacal-bursa arteries, predominantly one cloacal-bursa artery. Results are similar to those described by Santana et al. (1999) in Peterson hens and by Silva et al. (2003) in Label Rouge hens. These authors verified the existence of one to two right cloacal-bursa arteries rising from the right internal pudenda artery, with one very common artery. Similarly, studies by Santana et al. (2000) in matrixes of the Avian Farms strain and by Silva et al. (2001) in chickens of the same strain registered one to four right cloacal-bursa arteries.

The left internal pudenda artery also provided blood to the cloacal bursa in all analyzed specimens, providing frequently one, two or three left cloacal-bursa arteries. The above is similar to reports by Santana et al. (1999) in Peterson hens and by Silva et al. (2003) in Label Rouge hens. The same authors reported one to two left cloacal-bursa arteries; a single artery was, however, commonest. It must be underscored that, in spite of the occurrence of only one cloacal-bursa artery in the right and left antimeres in the most of studied rhea, the blood supply of the cloacal bursa was not jeopardized since it dorsally and laterally crossed the cloacal bursa till it reached the caudal-dorsal region, branching throughout the pathway. In fact, the organ received the necessary amount of blood for its physiological functions.

Scala et al. (1989) reported that branches from the right and left internal pudenda arteries in ducks (Anas platyrhynchos) penetrate the lateral margins and the ventral surface of the cloacal bursa, similar to the rhea, where the participation of the right and left cloacal arteries, the branches of the internal pudendal arteries, were reported. Such anatomical behavior may be related to the synoptic relationship of the vessel with the organ. The above is due to the fact that the cloacal arteries in all the specimens pass ventrally and laterally to the cloacal bursa till they reach the cloaca.

According to Santana et al. (1999), Silva et al. (2001), Santana et al. (2003) and Lima et al. (2008), the caudal quadrants of the cloacal bursas were abundantly supplied by vessels, which provided a greater blood amount than that reported for cranial quadrants. This fact has been observed in the rhea especially through the cloacal-bursa arteries. On the other hand, Santana et al. (2000) studied Avian Farms hen strains and observed that most of the arterial branches that supplied the cloacal bursa tended towards the cranial quadrants of the cloacal bursa and thus differed from that reported for the rhea.

Median caudal artery supplied the cloacal bursa in studies on different strains of Gallus gallus domesticus, such as Ross (SILVA et al., 1997), Peterson (SANTANA et al., 1999), Avian Farms (SANTANA et al., 2000), Hubbard (SANTANA et al., 2003), Hybro PG (GOMES et al., 2009) and Coob Slow (SINOTTI et al., 2012). The above were different from reports on the rhea since its artery did not irrigate the cloacal bursa. Maybe the lack of such an artery in the blood supply of the cloacal bursa in the rhea is related to its syntopy. In fact, its localization does not favor the emission of branches to the organ.

In current analysis the caudal mesenteric artery provided arterial blood to the cloacal bursa associated to the right and left internal pudenda arteries respectively in seven and eight specimens through anastomoses. These results were also given by Santana et al. (1999) in their study on Peterson hens and by Santana et al. (2003) on Hubbard strain matrixes. They reported anastomosis between the caudal mesenteric arteries and the right and left internal pudenda arteries with lesser frequency. On the other hand, Honorato et al. (2009) in their studies on the arteries of the cloacal bursa of ostriches reported the association of caudal mesenteric artery with the direct cloacal-bursa artery or with the left cloacal bursa, which was not reported in the rhea. Possibly the anastomoses produced alternative and collateral pathways or shortcuts that permitted a better maintenance of the blood circulation or they were a supply source when the more direct way was blocked and thus avoided the necrosis of the tissues of the cloacal bursa. 


\section{CONCLUSIONS}

The vessels that irrigate the cloacal bursa in the rhea are represented by cloacal-bursa arteries and by right and left cloacal arteries coming from the right and left internal pudenda arteries.

The caudal mesenteric artery participates in other arteries. Since the vessels that irrigate thecloacal bursa have branching and anastomosis patterns in the rhea, several individual variations occur. They are specific to the species and differentiate commonly reported standards for other fowls.

Knowledge on the vascularization of the cloacal bursa may be employed in anatomical and pathological examinations, sanitary inspection and in the biology of the species.

RESUMO: A bolsa cloacal é o órgão das aves responsável pela maturação e transferência de linfócitos para outros tecidos. Apesar da importância deste órgão nos mecanismos imunológicos das aves, são escassas as informações a respeito de sua morfologia em espécies silvestres, fato que ensejou descrever a vascularização arterial do mesmo em emas. Foram utilizadas 20 emas jovens (machos e fêmeas) obtidas no Centro de Multiplicação de Animais Silvestres (CEMAS/UFERSA), as quais vieram a óbito por causas naturais. Os animais foram dissecados e a aorta torácica canulada e perfundida com Látex Neoprene 650 corado com pigmento vermelho. Verificou-se que a irrigação da bolsa cloacal é originada a partir de ramos terminais da artéria aorta abdominal, tais como, as artérias ilíacas internas, direita e esquerda e a artéria mesentérica caudal. Das artérias ilíacas internas, direita e esquerda, originaram-se as artérias pudendas internas, direita e esquerda, que por sua vez deram origem às artérias bursocloacais e cloacais, direita e esquerda em todos os animais estudados. A artéria mesentérica caudal contribuiu com o aporte sanguíneo arterial da bolsa cloacal em quase todos os animais estudados, por meio de anastomose com a artéria pudenda interna direita ou com a artéria pudenda interna esquerda, mas também emitiu ramos diretamente a bolsa cloacal. A bolsa cloacal de emas é irrigada pelas artérias bursocloacais e cloacais direita e esquerda e ainda, pela artéria mesentérica caudal, podendo apresentar pequenas variações quanto ao número e disposição de anastomoses e ramos emitidos, peculiares à espécie, o que as diferenciam do padrão comumente reportado para outras aves.

PALAVRAS-CHAVE: Artéria bursocloacal. Artéria cloacal. Artéria mesentérica caudal. Aves. Ratitas. Sistema imunológico.

\section{REFERENCES}

ALMEIDA, M. A. Influência dos sistemas artificial e natural de incubação e criação de emas (Rhea americana) nos índices produtivos de criadores do Estado de São Paulo. 2003. 75 f. Master's Dissertation in Animal Reproduction, Faculdade de Medicina Veterinária e Zootecnia, Universidade de São Paulo, São Paulo, Brazil, 2003.

ABBATE, F.; PFARRER, C.; JONES, C. J. P.; CIRIACO, E.; GERMANÀ, G.; LEISER, R. Age-dependent changes in the pigeon Bursa of Fabricius vasculature: a comparative study using light microscopy and scanning electron microscopy of vessel casts. Journal of Anatomy, Malden, v. 211, n. 3, p. 387-398, 2007. http://dx.doi.org/10.1111/j.1469-7580.2007.00763.x

ACKERMANN, G. A. Electron microscopy of the bursa of Fabricius of the embryonic chick with particular reference of the lympho-epitelial nodules. Journal of Cell Biology, Columbus, v. 13, n. 1, p. 127-146, 1962. http://dx.doi.org/10.1083/jcb.13.1.127

BAUMEL, J. J. Functional morphology of the tail apparatus of the pigeon (Columba livia). Advanced in anatomy, embryology and cell biology, Heidelberg, v. 110, n. 1, p. 115-117, 1988.

BAUMEL, J. J.; KING, A. S.; BREAZILE, J. E.; EVANS, H. E.; BERGE, J. C. V. Handbook of avian anatomy: Nomina Anatomica Avium. 2 Ed. Cambridge: Nuttall Ornithological Club, 1993. 779 p.

FORTES, E. A. M.; SOUSA, A. F.; ALMEIDA, E. C. S.; CONDE JUNIOR, A. M.; MOURA, W. L. Morfologia das células do sangue periférico em emas (Rhea americana). Brazilian Journal of Veterinary Research and Animal Science, São Paulo, v. 46, n. 3, p. 215-221, 2009. 
FRAZIER, J. A. The ultrastructure of the lymphoid follicles of the chick bursa of Fabricius. Acta Anatomica, Atlanta, v. 88, n. 3, p. 385-397, 1974. http://dx.doi.org/10.1159/000144247

GOMES, A. R. A.; Silva, F. O. C.; MIRANDA, R. L.; RESENDE, G. G. N. Artérias da bolsa cloacal de galinhas (Gallus gallus) da linhagem Hybro PG. Biotemas, Florianópolis, v. 22, n. 4, p. 153-157, 2009.

HONORATO, A. G. O.; CARNEIRO E SIlvA, F. O.; ORTEGA, J. F.; PEREIRA, C. C. H. Artérias da bolsa cloacal de avestruzes (Struthio camelus). Veterinária Notícias, Uberlândia, v. 15, n. 2, p. 27-32, 2009.

LIMA, E. M. M.; SILVA, F. O. C.; SEVERINO, R. S.; DRUMMOND, S. S.; ARAÚJO, C. L.;

BOMBONATO, P. P.; SANTANA, M. I. S. Suprimento arterial para a bolsa cloacal em aves (Gallus gallus Linnaeus, 1758) da linhagem Lhoman White LSL. Biotemas, Florianópolis, v. 21, n. 1, p. 95-100, 2008. http://dx.doi.org/10.5007/2175-7925.2008v21n1p95

ONYEANUSI, B.; EZEOKOLI, C. D.; ONYEANUSI, J. C.; EMA, A. N. The anatomy of the cloacal bursa (Bursa of Fabricius) in the helmeted guinea fowl (Numida meleagris galeata). Anatomia, Histologia, Embryologia, Malden, v.22, n. 3, p. 212-221, 1993.

PARIZZI, R. C.; MIGLINO, M. A.; MAIA, M. O.; SOUZA, J. A.; SANTOS, J. M.; OLIVEIRA, M. F.; SANTOS T. C. Morfologia do ovário da ema (Rhea americana). Pesquisa Veterinária Brasileira, Seropédica, v. 27, n. 3, p. 89-94, 2007.

PEREIRA, A. V.; ROMANELLI, P. F.; SCRIBONI, A. B.; ORLANDINI, F. P. Rendimentos do abate e composição da carne de ema (Rhea americana). Ciência e Tecnologia de Alimentos, Campinas, v. 26, n. 3, p. 632-638, 2006. http://dx.doi.org/10.1590/S0101-20612006000300023

PINTEA, V.; CONSTANTINESCU, G. U.; RADU, C. Vascular and nervous supply of the bursa of Fabricius in the hen. Acta Veterinaria Academiae Scientiarum Hungaricae, Hungria, v. 17, n. 3, p. 263-268, 1967.

RODRIGUES, M. N.; OLIVEIRA, G. B.; SILVA, R. S. B., TIVANE, C.; ALBUQUERQUE, J. F. G.; MIGLINO, M. A.; OLIVEIRA, M. F. Macroscopia e topografia do aparelho digestório de emas (Rhea americana americana). Pesquisa Veterinária Brasileira, Seropédica, v. 32, n. 7, p. 681-686, 2012 a.

RODRIGUES, M. N.; TIVANE, C. N.; CARVALHO, R. C.; OLIVEIRA, G. B.; SILVA, R. S. B.; AMBROSIO, C. E.; OLIVEIRA, M. F.; MIGLINO, M. A. Gross morphology of rhea oropharyngeal cavity. Pesquisa Veterinária Brasileira, Seropédica, v. 32, n. 1, p. 53-59, 2012 b.

ROSA, M. C. B.; GUIMARÃES, G. C.; NARCISO, T. P.; BASTOS, P. M.; NASCIMENTO, L. G.; SANTANA, M. I. S.; LIMA, E. M. M. Vascularização da bolsa cloacal em Gallus gallus domesticus (Linhagem Master Gris Cou Plumé). Bioscience Journal, Uberlândia, v. 30, n. 2, p. 484-490, 2014.

SANTANA, M. I. S.; CARNEIRO E SILVA, F. O.; SEVERINO, R. S.; BOMBONATO, P. P.; MARÇAL, A. V. Irrigação da bolsa cloacal em Gallus gallus domesticus (matrizes de corte Hubbard). Brazilian Journal of Veterinary Research and Animal Science, São Paulo, v. 40, n. 1, p. 199-204, 2003.

SANTANA, M. I. S.; CARNEIRO E SILVA, F. O.; SEVERINO, R. S.; SANTOS, A. L. Q.; DRUMMOND, S. S.; BOMBONATO, P. P. Irrigação da bolsa cloacal, em aves reprodutoras, da linhagem Peterson (Gallus gallus domesticus). Brazilian Journal of Veterinary Research and Animal Science, São Paulo, v. 36, n. 2, p. 59-65, 1999.

SANTANA, M. I. S.; CARNEIRO E SILVA, F. O.; SEVERINO, R. S.; SANTOS, A. L. Q.; DRUMMOND, S. S.; BOMBONATO, P. P. Vascularização arterial da bolsa cloacal em Gallus gallus domesticus (Matrizes de corte Avian Farms). Brazilian Journal of Veterinary Research and Animal Science, São Paulo, v. 37, n. 2, p. 115-120, 2000. 
SANTOS, T. C.; SOUSA, J. A.; OLIVEIRA, M. F.; SANTOS, J. M.; PARIZZI, R. C.; MIGLINO, M. A. Morfologia dos órgãos genitais masculinos e da cloaca da ema (Rhea americana americana). Pesquisa Veterinária Brasileira, Seropédica, v. 31, n. 5, p. 430-440, 2011.

SCALA, G.; CAPUTO, G.; PAINO, G.; PELAGALLI, G.V. The vascularization of the bursa cloacalis (of Fabricius) in the duck. Anatomia, Histologia, Embryologia, Malden, v. 18, n. 1, p. 66-75, 1989.

SILVA, F. O. C.; SEVERINO, R. S.; DRUMMOND, S. S.; BOMBONATO, P. P.; SANTANA, M. I. S.; LIMA, E. M. M. Irrigação da bolsa cloacal em aves (Gallus gallus Linnaeus, 1758) da linhagem NPK. Arquivos de Ciências da Saúde da UNIPAR, Umuarama, v. 5, n. 1, p. 17-24, 2001.

SILVA, F. O. C.; SEVERINO, R. S.; DRUMMOND, S. S.; MACHADO, G. V.; BOMBONATO, P. P.; SANTANA, M. I. S.; LIMA, E. M. M. Suprimento arterial para a bolsa cloacal de galinhas (Gallus gallus Linnaeus, 1758) da linhagem Label Rouge. Archives of Veterinary Science, Curitiba, v. 8, n. 1, p. 13-18, 2003.

SILVA, F. O. C.; SEVERINO, R. S.; SANTOS, A. L. Q.; DRUMMOND, S. S.; BOMBONATO, P. P.; SANTANA, M. I. S.; GONÇALVEZ, P. O.; MARÇAL, A. V. Vascularização arterial da bolsa cloacal em Gallus gallus domesticus (Linhagem Ross). Revista da FZVA, Porto Alegre, v. 4, n. 1, p. 81-92, 1997.

SINOTTI, J. F.; MARTINS, A. B.; BIRCK, A. J.; FILADELPHO, A. L. Vascularização arterial da bolsa cloacal em (Gallus gallus domesticus) da linhagem Coob Slow. Revista Científica Eletrônica de Medicina Veterinária, Garça, v. 19, n. 2, p. 1-10, 2012.

ZAMOJSKA, D. Anatomical studies on the vascularization of the bursa of Fabricius and Uropigeal gland in the hens (Gallus domesticus). Part II. Blood vessels of the bursa of Fabricius (Bursa of Fabricii). Zoologica Poloniae, Wrocław, v. 24, n. 1, p. 455-476, 1975. 